\title{
The Effect of E-Learning on the Student's Learning Outcome in Higher Education
}

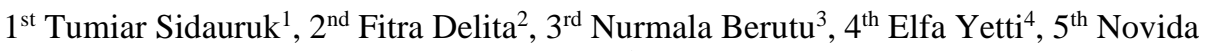 \\ Yenny $^{5}$ \\ \{tumiargeo@yahoo.com ${ }^{1}$, delitafitra@gmail.com ${ }^{2}$, nurmalageo@yahoo.com ${ }^{3}$ \} \\ Department of Geography Education, Faculty of Social Sciences, Universitas Negeri Medan, \\ Indonesia ${ }^{1,2,3,4,5}$
}

\begin{abstract}
Recently, e-learning has become a popular method that is widely used and implemented by all educational institutions. The objective of this research is to analyze the effect of e-learning implementation on student's learning outcome. The study adopted a pretest-posttest experimental approach. There are 40 students in 2 classes are selected as participants of the research. The experimental groups using e-learning and the controls group by face to face learning. The computer statistics software SPSS version 20 is used for data analysis. According to the result, the posttest mean in learning outcome among the students in the experimental group is statistically significantly higher than the corresponding mean among the students in the control group. Therefore, it can be concluded that e-learning shows better positive effects on student's learning outcomes than traditional teaching in higher education. Also, the e-learning activities are more effective for learning compared to face to face learning.
\end{abstract}

Keywords: e-learning, learning outcome, higher education.

\section{Introduction}

The Covid-19 pandemic has an impact on various areas of life in countries around the world, including Indonesia. This impact is also felt in the field of education where the implementation of face-to-face education in classrooms shifts to learning in virtual spaces through various e-learning platforms. The differences between e-learning and traditional learning included learning material [1], learning environment [2], learning modes and teaching methods [3]. Several benefit of e-learning such as effective and flexible in terms of time and location [4], easy to organize learning material with digital contents [5], interactive learning [6], record of learning history completely [7] and improve of learning interests [8]. The purpose of this study is to measure the impact of e-learning on learning outcomes in the Geography Learning Outcomes Evaluation course. This research is needed because this is the first time e-learning has been fully implemented for one semester. The results of the research will be taken into consideration for the improvement of the next learning process, as well as enriching references on e-learning at the higher education level. 


\section{Method}

This research is a quasi-experimental research with a control group and an experimental group. The control group consisted of 20 students and the experimental group consisted of 20 students. The experimental group participated in online learning activities via SIPDA (an elearning platform developed by the Medan State University), while the control group participated in face-to-face learning activities in the classroom. Data collection was carried out through observation and tests (pretest and posttest). The test was developed by the researcher, which consists of 15 multiple choice and 5 fill-the-blank questions. The validity of this instrument has been tested with KR-20 reliability. The pretest and posttest data were analyzed using independent samples t-test.

\section{Results and Discussion}

In the first session, the lecturer explained the Semester Learning Plan (RPS) document which contained material, lecture activities, assignments, exams, and an assessment system. The pretest implementation in the second week was carried out simultaneously between the experimental class and the control class. The results of this pretest can be observed in Table 1 below:

Table 1. Summary of independent t-test on difference of pretest.

\begin{tabular}{lccccc}
\hline Group & $\mathrm{N}$ & Mean & $\mathrm{SD}$ & $\mathrm{t}$ & $\mathrm{p}$-value \\
\hline Experimental & 20 & 12.89 & 3.1 & & \\
Control & 20 & 11.58 & 1.61 & 1.65 & .108 \\
\hline
\end{tabular}

Table 1 shows that the mean value in the experimental class (12.89) is higher than the mean value in the control class (11.58). The difference between the mean values in the two classes is 1.31. The mean difference between the experimental class and the control class was not statistically significant because the value of $t=1.65$, $\mathrm{p}$-value $=0.108>0.05$. This means that the initial abilities of the two groups are almost the same (there is no significant difference). The posttest was held during the eighth session. The results of the posttest in the experimental class and control class are listed following table:

Table 2. Summary of independent t-test on difference of posttest.

\begin{tabular}{lccccc}
\hline Group & $\mathrm{N}$ & Mean & SD & t & p-value \\
\hline Experimental & 20 & 16.04 & 2.33 & & \\
Control & 20 & 13.16 & 1.40 & 4.7 & .000 \\
& & & & 3 & \\
\hline
\end{tabular}

As shown in Table 2, the results of the independent t-test analysis on the posttest indicated that the mean value in the control group (face-to-face learning) was 13.16, while the mean in the experimental group (e-learning) was 16.48. The mean difference between the two 
groups was 2.98. When seen from the $t$ value (4.73) with $p=.000<.001$, there is a significant difference in learning outcomes between e-learning and face-to-face learning.

E-learning in lectures can be designed using various platforms, for example Google Classrooms, Schoology or those developed by schools / universities. This platform can also be combined with other applications such as Zoom Meeting, Cisco Webex, or Google Meet for live streaming interactions, Google Forms, Quizzy, i-Spring for evaluation in the form of tests, as well as WhatsApp, Facebook, YouTube and other social media that can be used to share learning material and other learning activities. In this study, the e-learning used is SIPDA, a platform developed by the State University of Medan. All lecture activities such as materials, presentations, discussions, assignments, exams, and assessments in e-learning classes are managed at SIPDA. The industrial era 4.0 has an impact on digital-based learning [9]. Implementation of technology-based learning such as e-learning is very appropriate in this era. Learning can be done anywhere and anytime if e-learning is applied [10]. The ease with which students can access lessons will increase their interest and motivation to study [11][12].

Based on the results of the questionnaire, $89.65 \%$ of students participating in e-learning were satisfied with this learning method. They feel more flexible in learning, both in terms of place, time, and cost. This shows the effectiveness of e-learning as a learning method. The increase in online learning time can improve the learning performance of students [12]. Not only is it more effective, e-learning has also been proven to improve student learning outcomes. Digital learning is intended for student activeness in learning activities to achieve a set of learning outcomes [14] [15]. Students are more courageous in expressing ideas, asking questions, and having more active discussions during e-learning. Materials can also be accessed more easily from various digital sources such as e-books and e-journals.

E-learning makes it easier for students to share ideas, find data and analyze them individually or in groups and communicate virtually. This course will improve critical thinking skills, creativity, collaboration, and communication as skills that must be achieved in 21 st century learning. In addition, in ICT-based assignments and exams, students are required to be more disciplined in collecting assignments and examinations. As such, e-learning not only improves cognitive abilities but also builds affective and psychomotor abilities as components of the learning outcome. E-learning is also part of environmentally friendly learning because it can reduce paper usage. So far, conventional learning systems have increased the use of paper at various levels of education. This will have a negative impact on the environment, such as increased tree cutting and paper waste that is not recycled.

\section{Conclusion}

E-learning is a solution for the implementation of the teaching and learning process during the Covid-19 pandemic as well as part of the characteristics of 21 st century learning which is directed at innovative learning through the use of technology. E-learning can have a positive impact on the learning outcomes of students. The learning outcomes are not only visible in the cognitive aspects, but also in the affective and psychomotor aspects. Besides being effective in terms of achieving learning outcomes, e-learning also reduces paper use and helps preserve the environment. The success of e-learning is largely determined by the students' internal factors, which are self-regulated and self-directed, the ease and speed of internet access and the management of learning from educators. 
Acknowledgments. We are grateful to the Research and Community Service Institute Universitas Negeri Medan for funding this study.

\section{References}

[1] McKiernan G. Configuring the 'Future Textbook'. Search. 2011; 19(4):43-47.

[2] Chesser WD. Chapter 5: The E-textbook Revolution. Library Technology Reports. 2011; 47(8):2840.

[3] Yien JM, Hung CM, Hwang GJ, Lin YC. A game-based learning approach to improving students' learning achievements in a nutrition course. Turkish Online J Edu Tech. 2011; 10(2):1-10.

[4] Jude LT, Kajura MA, Birevu. Adoption of the SAMR model to assess ict pedagogical adoption: A case of Makerere University. Int J e-Education, e-Business, e-Management and e-Learning. 2014; 4(2):106-115.

[5] Im I, Hong S, Kang. An international comparison of technology adoption testing the UTAUT model. Information \& Management. 2011; 48(1):1-8.

[6] Hockly N. Substitute or redefine? Modern English Teacher. 2012; 21(3):40-42.

[7] Sun JY, Han SH, Huang W. The roles of intrinsic motivators and extrinsic motivators in promoting e-learning in the workplace: A case from South Korea. Comp in Human Behavior. 2012; 28(3): 942-950.

[8] Kaklamanou D, Pearce J, Nelson M. Food and Academies: A Qualitative Study. Department for Edu. 2012:1-23

[9] Kaur G. Digital Life: Boon or bane in teaching sector on COVID-19. CLIO an Annual Interdisciplinary J History. 2020; 6(6):416-427.

[10] Liguori E, Winkler C. From offline to online: Challenges and opportunities for entrepreneurship education following the COVID-19 pandemic. 2020; 3(4):346-351.

[11] Toquero CM. Challenges and opportunities for higher education amid the COVID-19 pandemic: The Philippine context. Pedagogical Research. 2020; 5(4):1-5.

[12] Pace C, Pettit SK, Barker KS. Best practices in middle level quaranteaching: Strategies, tips and resources amidst COVID-19. Becoming: Journal of the Georgia Association for Middle Level Education. 2020: 31(1);1-13.

[13] Berutu N, Delita F, Astuti AJD, Novira N, Wirda MA. The Strategy To Strengthen Information Literacy Based On Library and Digital Resources. Proceedings of the 1st International Conference on Social Sciences and Interdisciplinary Studies (ICSSIS 2018); 14th -15th November 2018; Medan. Atlantis Press; 2019. p. 144-147.

[14] Delita F, Arif M, Rosni, Sitompul M, Rohani. Improving The Quality of Learning Through Assignment System. J Phys: Conf Ser. 2019; 1175:1-4. 